\title{
कोभिड - १९ ले नेपालको अर्थतन्त्रमा पारेको प्रभाव र यसको नियन्त्रणका प्रयास
}

\section{रमेश अर्याल}

\section{लेखसार}

विश्वभर महामारीका रुपमा फैलिएको कोभिड - 99 २१ औं शताव्दीको सबैभन्दा ठलो सड्कटको रुपमा देखापरेको छ। यस महामारीका कारण विश्वले मानवीय र आर्थिक सड़कट एकैपटक सामना गरेको छ। यसले विश्व अर्थतन्त्रको समग्र उत्पादन, उत्पादकत्व एवम आपर्ति प्रणालीमा प्रतिकल प्रभाव पारेको छ। यसले सिर्जना गरेको असहज परिस्थितिले नेपालको अर्थतन्त्र र जनजीवनमा समेत गम्भीर असर परेको छ। पहिल्लो तीन वर्षदेखि नेपालमा उच्च आर्थिक वृद्धिदर हुँदै आएकोमा यस महामारीले पर्यटन, होटल, यातायात, सज्चार, उत्पादनमलक उद्योग, खानी र निर्माण लगायतका क्षेत्रको कियाकलाप सङकुचित भई आर्थिक वर्ष २०७६/७७ मा आर्थिक वृद्धिदर न्यन भएको छ भने चालु आर्थिक वर्ष २०७७/७५ मा पनि सरकारले लिएको लक्ष्यभन्दा न्यन हुने अनुमान छ। वैदेशिक व्यापार, शोधानान्तर स्थिति लगायतका बाह्रय क्षेत्र बाहेक अर्थतन्त्रका अन्य सबै क्षेत्रमा यसले असर गरेको छ। बेरोजगारीको संख्या बढ़दै जाँदा निरपेक्ष गरिबीको रेखामुनी रहेको जनसंख्या बढ़ने देखिएको छ। अन्तर्राष्ट्रिय संस्थाहरुका साथै सरकारी निकायहरुले यस महामारीले अर्थतन्त्रका विभिन्न पक्षमा पार्ने असरका बारेमा विभिन्न प्रक्षेपण एवम अध्ययन गरेका छन् यद्यपि यसले अर्थतन्त्रमा पारेको प्रभाव र प्रयास सम्बन्धमा एकीकत अध्ययन भएको छैन यस लेखमा महामारीले नेपालको अर्थतन्त्रमा पारेको प्रभाव र यसको
नियन्त्रणका लागि भएका प्रयासहरुका बारेमा विश्लेषण गरिएको छ। द्वितीय स्रोतमा आधारित यस अध्ययनमा विश्लेषणात्मक तथा वर्णनात्मक अध्ययन पद्धतिको प्रयोग भएको छ। यस महाहामारीले अर्थतन्त्रमा पारेको प्रभाव र चुनौतीका सम्बन्धमा अन्तर्राष्ट्रिय संस्था तथा सरकारी निकायले प्रकाशन गरेका दस्तावेज तथा अर्थशास्त्रीहरुले व्यक्त गरेका विचारलाई आधार मानी यो अध्ययन गरिएको छ। यस महामारीबाट अर्थतन्त्रमा परेको असर तथा प्रभावलाई न्यनीकरण गर्न स्वास्थ्य सुरक्षाका मापदण्ड अपनाउँदै राहत तथा पुनरुत्थानका कार्यकमको कार्यान्वयनमा जोड दिएर अर्थतन्त्रलाई चलायमान बनाउन सम्बद्ध पक्ष प्रतिवद्ध र कटिवद्ध हुनुपर्ने देखिन्छ।

शब्दकुर्जी : कोभिड- १९, महामारी, लकडाउन, अर्थतन्त्र, आर्थिक वृद्धिदर, पुनरुत्थान, राहत

\section{परिचय}

विश्व स्वास्थ्य संगठनका अनुसार सन् २०१९ को डिसेम्बर ३१ मा चीनको बुहान सहरबाट सुरु भएको कोरोना भाइरसको प्रकोप हाल संसारभर फैलिएको छ। विश्व स्वास्थ्य सझुनले सन् २०२० जनवरी ३० मा यसलाई अन्तर्राष्ट्रिय सरोकारको आकस्मिक स्वास्थ्य समस्या भनी उल्लेख गर्नुका साथै सन् २०२० फेब्रुअरी ११ मा यस रोगको नाम कोभिड - १९ (कोरोना भाइरस डिजिज २०१९) राखेको थियो। साथै, सन् २०२० मार्च ११ मा यस रोगलाई विश्वव्यापी 
महामारीको रुपमा घोषणा भएको थियो । (World Health Organization, 2021)

शर्मा (२०७७) को विवरण अनुसार नेपालमा सन् २०२० जनवरी २३ तदनुसार २०७६ माघ ९ गते पहिलो पटक कोभिड - १९ को संकमण वुहानबाट फर्किएका विद्यार्थीमा देखिएको थियो। दोस्रो पटक युरोपबाट फर्किएकी विद्यार्थीमा २०२० मार्च २३ मा देखापरेको थियो। २०२० मे १४ मा पहिलो पटक यस रोगबाट प्रभावित नेपालीको मृत्यु भएको थियो। (शर्मा, २०७७, पृ.१६४)

विश्व स्वास्थ्य संगठनको कोभिड - १९ ड्यासवोर्ड अनुसार सन् २०२१ फेब्रअरी ६ (२०७७ माघ २३) सम्म कोभिड - १९ का कारण विश्वमा १० करोड ४३ लाखभन्दा बढ़ी व्यक्तिमा यसको संक्रमण पुष्टि भएको छ भने यसबाट मृत्यु हुनेको संख्या २२ लाख ७ हजारभन्दा माथि पुगेको छ। त्यस्तै, नेपालमा ? लाख ७१ हजारभन्दा बढ़ी व्यक्ति यस रोगबाट संक्रमित भएका छन् भने २ हजार ३३ जनाको मृत्यु भएको छ। कोभिड - 99 ले मानव जीवन र सभ्यतामाथि नै चुनौती खडा गरेको छ। संयुक्त राष्ट्र संघका महासचिव एन्टियो गुटिरेजको विचार अनुसार यस महामारीले दोस्रो विश्वयुद्ध पछिको सबैभन्दा ठूलो सङकट सिर्जना गरेको छ। यो संयुक्त राष्ट्रसंघ स्थापनापछिको विश्व समुदायले सामना गर्नुपरेको अत्यन्तै गम्भीर चुनौती हो (महत, २०७७, पृ.१५६)

सन् १९३० को विश्व अर्थिक महामन्दीपछिको सबैभन्दा जटिल अवस्थाबाट अहिले संसार गुज्रिरहको छ। विगतका सङकट कि मानवीय हुन्थे कि आर्थिक, तर यसपटक मानवीय र आर्थिक सङकट एकैपटक आइपरेको छ। कोभिड - १९ का कारण हरेक देश र त्यहाँका नागरिक आफू र आफ्ना परिवार कसरी बचाउने भनी एकातिर चिन्तित हुनु परेको छ भने अर्कोतिर जीविका चलाउनका लागि सङघर्ष गर्नुपरेको छ।
कोभिड - १९ को संकमण निरन्तर बढ़दै गएको छ। यो कहिले अन्त्य हुन्छ र यसले कति क्षति पुरयाउँछ भन्ने अनुमान गर्न गाह्रो छ। विश्वले एकैपटक मानव स्वास्थ्य तथा अर्थिक सङकट व्यहोर्नुपरेको कारण गरिबी, बेरोजगारी र आय असमानता बढ्ने अनुमान छ (अर्थ बुलेटिन, २०७७, पृ. २) कोभिड - १९ ले क्षेत्रगत रुपमा एकैनासको प्रभाव नपारेर कुनै क्षेत्रलाई तत्कालको लागि प्रभाव पारेको छ भने कुनै क्षेत्रमा यसको दीर्घकालीन असर पर्ने देखिन्छ (अधिकारी, २०७७, पृ.ख) अर्थिक सर्वेक्षण २०७६/७७ का अनुसार आर्थिक वर्ष २०७६/७७ को फागुन मसान्तसम्म समष्टिगत आर्थिक परिसूचकहरु सन्तुलित र सन्तोषजनक रहेकोमा यस रोगको संकमण रोकथाम, नियन्त्रण तथा उपचारको लागि अवलम्वन गरेका उपायहरुले समग्र अर्थतत्त्र प्रभावित भएको छ।

यस रोगका कारण अर्थतन्त्र शिथिल रहेको छ । आर्थिक वृद्धिदरमा गम्भीर असर परेको छ। सार्वजनिक वित्तअन्तर्गत राजस्व सङकलन लक्ष्यअनुसार नहुने, चालु खर्चमा चाप, पुँजीगत खर्चमा शिथिलता, सार्वजनिक ऋणमा बढोत्तरी हुने देखिएको छ। यस रोगले बेरोजगार बढ़ी गरिब जनताको संख्या बढ़ने देखिन्छ। खतिवडा (२०७७) को विचार अनुसार हरेक सङकट पछि अर्थिक वृद्धि, आय र सम्पत्तिको वितरणमा नयाँ प्रवृत्ति देखापर्ने गई। आर्थिक सङकट केहीका लागि अवसर र बाँकीका लागि दुर्भागय बन्न पुग्छ। यस रोगबाट पछाडि प्रतिव्यक्ति आय घट्नेछ। आम्दानी र अवसर गुम्दा त्यसले असमानता अभै बढाउँछ। सबैभन्दा कमजोर वर्गको अवसर छिटो गुम्ने भएकाले आय असमानता अभ बढ़छ। (खतिवडा, २०७७, पृ.१२६)

कोभिड - १९ ले विपद्मा राज्यको भूमिका र दायित्व बढी हुने कुराको पुष्टि भएको छ। यसले स्वास्थ्य पूर्वाधार तथा जनशक्ति, अनुसन्धान, सेवाप्रवाहमा सूचना प्रविधिको प्रयोग, कृषि क्षेत्रमा लगानी लगायतका विषयमा राज्यले बढी जोड दिनुपर्ने रहेछ भन्ने पाठ सिकाएको छ। 
राष्ट्रिय योजना आयोग र संयुक्त राष्ट्रसंघीय विकास कार्यकमले प्रकाशन गरेको नेपाल मानव विकास प्रतिवेदन २०२० मा सबल अर्थतन्त्र र सार्वजनिक स्वास्थ्य बिच अन्योन्याश्रित सम्बन्ध हुने भएकोले यस महामारीले कोभिड - १९ महामारीले स्वास्थ्य पूर्वाधारमा लगानी गर्न पाठ सिकाएको उल्लेख छ (NPC \& UNDP, 2020, P. 164) । यस रोगको असरबाट छुटकारा पाउन संसारका सबै देशले अर्थतन्त्रलाई चलायमान बनाइ राख्नका लागि विभिन्न राहत तथा आर्थिक पुनरुत्थानका कार्यकमहरु कार्यान्वयनमा ल्याएका छन् नेपाल सरकारले पनि उद्धार, राहत तथा आर्थिक पुनरुत्थानका कार्यकमहरु तर्जुमा गरी कार्यान्वयनमा ल्याएको छ। महामारीबाट बच्न २०७६ चैत्र ११ गतेबाट लकडाउनको भई २०७७ जेठ मसान्तसम्म आधारभूत बाहेकका आर्थिक कियाकलाप बन्द भएका थिए। २०७७ असार १ देखि लकडाउन खुकुलो बनाउँदै लगिएकोमा हाल लकडाउन हटेको अवस्था छ।

नेपाल सरकारले समृद्ध नेपाल सुखी नेपालीको राष्ट्रिय आकांक्षा हासिल गर्ने लक्ष्य लिएको छ। वि.सं. २०७९ सम्ममा अति कम विकसित राष्ट्रबाट विकासशील राष्ट्रमा स्तरोन्नति गर्ने, वि.सं. २०६७ सम्ममा दिगो विकासका लक्ष्यहरु हासिल गर्दे उच्च मध्यम आयस्तर भएको मुलुकमा स्तरोन्नति गर्ने र वि.सं. २१०० सम्ममा समुन्नत राष्ट्रको स्तरमा पुच्याउने दीर्घकालिन सोच सरकारले लिएको छ। विश्वमा महामारीको रुपमा फैलिएको कोभिड - 99 ले समृद्ध नेपाल सुखी नेपालीको आकांक्षा पूरा गर्न चुनौती थपेको छ।

कोभिड - १९ ले अर्थतन्त्रमा पारेको प्रभावका सम्बन्धमा विभिन्न निकायले छुट्टाछुट्टै अध्ययन गरेको भए पनि अर्थतन्त्रका समग्र पक्षमा पारेको प्रभाव र नियन्त्रणका प्रयासलाई एकीकृत गरी अध्ययन गरेको पाइदैन। यस रोगले नेपालको अर्थतन्त्रमा कस्तो प्रभाव पारेको छ ? यस रोगको नियन्त्रणका लागि कस्ता प्रयास भएका छन् ? र यसको नियन्त्रण तथा अर्थतन्त्र चलायमान गराउनका लागि थप के के गर्नुपछ ? लगायतका
विषयलाई यस लेखमा समस्याको रुपमा लिइएको छ।

\section{२. अध्ययन उद्देश्यहरु}

कोभिड - १९ ले नेपालको अर्थतन्त्रमा पारेको प्रभाव बारे अध्ययन गर्नु यस लेखको मुख्य उद्देश्य हो यसका अन्य उद्देश्यहरु यस रोगको नियन्त्रणका लागि भएका प्रयासहरु बारे जानकारी गराउनु तथा यस रोगको नियन्त्रण गर्न र अर्थतन्त्र चलायमान बनाउन सुभाव दिनु हो ।

\section{अध्ययन विधि}

द्वितीयक स्रोतमा आधारित यस अध्ययनमा विश्लेषणात्मक तथा वर्णनात्मक अध्ययन पद्धतिको प्रयोग भएको छ। कोभिड - १९ ले अर्थतन्त्रमा पारेको प्रभाव र चुनौतीका सम्बन्धमा विश्व बैंक, अन्तर्राष्ट्रिय मुद्रा कोष, एसियाली विकास बैंक लगायतका अन्तर्राष्ट्रिय संस्था तथा राष्ट्रिय योजना आयोग, अर्थ मन्त्रालय, नेपाल राष्ट्र बैंक, केन्द्रीय तथ्याङक विभाग, महालेखा नियन्त्रक कार्यालय लगायतका सरकारी निकायले प्रकाशन गरेका दस्तावेज तथा अर्थशास्त्रीहरुले पत्रपत्रिकामा व्यक्त गरेका विचार, पत्रपत्रिकामा प्रकाशित समाचार सामाग्रीको समीक्षा र संश्लेषणलाई आधार मानी यो अध्ययन गरिएको छ।

अर्थतन्त्रमा चार मुख्य क्षेत्र छन्; ती हुन वास्तविक क्षेत्रमा आर्थिक वृद्धिदर, मुद्रास्फीति भने सार्वजनिक वित्त क्षेत्रमा राजस्व, सार्वजनिक खर्च, सार्वजनिक ऋण पई । त्यस्तै मौद्रिक क्षेत्रमा बैंकिड्र तथा वित्तीय क्षेत्र पई । बाहय क्षेत्रमा वैदेशिक व्यापार, शोधानान्तर स्थिति, विप्रेषण, विदेशी विनिमय सज्चिति लगायतका विषय पई्छन् गरिबी र बेरोजगारीमा यी सबै क्षेत्रले प्रभाव पारेको हुन्छ । यस लेखमा अर्थतन्त्रका यी क्षेत्रमा कोभिड - 99 ले पारेको प्रभाव बारेमा विश्लेषण गरिएको छ। यसको अवधारणात्मक ढाँचा निम्नानुसार छ : 
चित्र १ : कोभिड -१९ ले अर्थतन्त्रमा पारेको प्रभावको अवधारणात्मक ढाँचा

\section{Independent Variable}

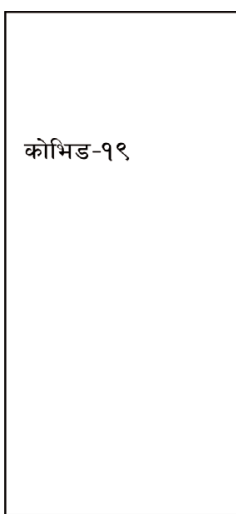

कोभिड - १९ ले अर्थतन्त्रका विविध क्षेत्रमा प्रभाव पार्ने भएकोले यो रोग स्वतन्त्र चर (Independent Variable) का रुपमा रहेको छ भने अर्थतन्त्रका क्षेत्रहरु आश्रित चर (Dependent Variable) का रुपमा उल्लेख गरिएको छ।

कोभिड-१९ ले अर्थतन्त्रमा पारेको प्रभावको विश्लेषण कोभिड - १९ ले अर्थतन्त्रका विभिन्न क्षेत्रमा पारेको प्रभाव पारेको छ जसलाई निम्नानुसार देखाउन सकिन्छ :

\section{(क) आर्थिक वृद्धिमा पारेको प्रभाव}

कोभिड-१९ का कारण विश्व अर्थतन्त्र सङकुचनमा गएको छ। यसका कारण समग्र उत्पादन, उत्पादकत्व

\section{Dependent Variable}

- अर्थिक बृद्धिदर

- राजस्व

- सार्वजनिक खर्च

- वैदेशिक सहायता

- सार्वजनिक ऋण

- मौद्रिक क्षेत्र

- मुद्रास्फीति

- पूँजी बजार

- बाह्य क्षेत्र

- गरिबी र बेरोजगारी

एवम् आपर्ति प्रणालीमा प्रतिकल प्रभाव परेको छ, । अन्तर्राष्ट्रिय मुद्राकोषले २०२० अक्टोवरमा प्रकाशित गरेको वर्ल्ड इकोनोमिक आउटलुक अनुसार विश्व अर्थतन्त्र सन् २०१९ मा २.द प्रतिशतले विस्तार भएकोमा सन् २०२० मा ४. ४ प्रतिशतले सङकुचन हुने प्रक्षेपण छ। विकसित मुलुकहरुको अर्थतन्त्र सन् २०२० मा प.द प्रतिशतले सङकुचन हुने प्रक्षेपण छ। सन् २०२० मा उदीयमान तथा विकासशील अर्थतन्त्र ३.३ प्रतिशतले तथा उदीयमान तथा विकासशील एशियाली अर्थतन्त्र १.७ प्रतिशतले सङ्कुचन हुने प्रक्षेपण छ। सन् २०२१ मा विश्व अर्थतन्त्र ५. २ प्रतिशतले विस्तार हुने अनुमान छ। (International Monetary Fund, 2020, p. 141)

तालिका १: विश्व आर्थिक वृद्धिदर (प्रतिशतमा)

\begin{tabular}{|c|c|c|c|c|c|c|c|}
\hline अर्थतन्त्र & २०१Y & २०१६ & २०१७ & २०१६ & २०१९ & $\begin{array}{l}\text { २०२० } \\
\text { (प्रक्षेपण) }\end{array}$ & $\begin{array}{l}\text { २०२१ } \\
\text { (प्रक्षेपण) }\end{array}$ \\
\hline विश्व अर्थतन्त्र & ३. ४ & ३.३ & ३.ॅ & ३.y & २. ᄃ & $-\gamma . \gamma$ & y. 2 \\
\hline विकसित अर्थतन्त्र & २. ४ & 9.5 & २.Y & २.२ & 9.9 & -4.5 & ३.९ \\
\hline उदीयमान तथा विकसित अर्थतन्त्र & ४.३ & $\gamma . y$ & r.द & $\gamma . y$ & ३.७ & -३.३ & $\xi .0$ \\
\hline उदीयमान तथा विकासशील एसिया & $\xi . \zeta$ & $\xi . \varsigma$ & $\xi . \vartheta$ & $\xi . ३$ & $y . y$ & -9.9 & ᄃ.O \\
\hline उदीयमान तथा विकासशील युरोप & 9.0 & 9.9 & 8.9 & ३.३ & २.१ & $-\gamma . \xi$ & ३.९ \\
\hline मध्यपूर्व तथा उत्तर अफ्रिकी मुलुक & २.Y & ४.९ & २.० & 9.2 & 0.5 & -4.0 & ३.२ \\
\hline युरोपियन युनियनका मुलुकहरु & २.Y & २.१ & ३.० & २.३ & $9 . \vartheta$ & $-७ . \xi$ & $y .0$ \\
\hline न्यन आय भएका विकासशील अर्थतन्त्र & $\gamma . \vartheta$ & ३.९ & $\gamma . \rho$ & $y .9$ & $y . \xi$ & -9.2 & $\gamma . \rho$ \\
\hline
\end{tabular}


सन् २०२० मा दक्षिण एशियाली मुलुकहरुमध्ये बंगलादेशको ३.५ प्रतिशतले तथा भुटानको ०.६ प्रतिशतले आर्थिक वाद्धिद्धर हुने अनुमान छ। माल्दिभ्सको अर्थतन्त्र १६.६ प्रतिशतले र भारतको अर्थतन्त्र १०.३ प्रतिशतले सङकुचन हुने प्रक्षेपण छ। नेपालको आर्थिक वृद्धि भने शून्य प्रतिशतमा सीमित हुने अनुमान अन्तर्राष्ट्रिय
मुद्राकोषले गरेको छ। छिमेकी देश चीनको अर्थतत्त्र १.९ प्रतिशतले विस्तार हुने प्रक्षेपण छ। सन् २०२१ मा भुटानको बाहेक दक्षिण एशियाली देशको आर्थिक वृद्धिदर बढ़ने अन्तर्राष्ट्रिय मुद्राकोषको अनुमान छ । (International Monetary Fund, 2020, P. 145)

तालिका २ : दक्षिण एशियाली मुलुक र चीनको आर्थिक वृद्धिदर (प्रतिशतमा)

\begin{tabular}{|c|c|c|c|c|c|c|c|}
\hline देश & 209Y & २०१६ & २०१७ & 2095 & 2099 & २०२० (प्रक्षेपण) & २०२१ (प्रक्षेपण) \\
\hline बड़लादेश & $\xi . \xi$ & ७.9 & ৩. ३ & ७. & ५.२ & ३. द & ४. \\
\hline भुटान & $\xi . २$ & ७. ४ & $\xi . ३$ & ३. द & ३. ५ & $0 . \xi$ & $-0 . y$ \\
\hline भारत & ร. 0 & ๘.३ & ७. 0 & $\xi .9$ & ४. २ & -90.3 & ᄃ.ร \\
\hline माल्दिभ्स & २.९ & $\xi . ३$ & $\xi . \zeta$ & $\xi . \rho$ & $y .0$ & $-9 \sqsubset . \xi$ & १२.७ \\
\hline नेपाल & ३.३ & $0 . \xi$ & ५.२ & $\xi . ७$ & ७. 9 & 0.0 & २.Y \\
\hline पाकिस्तान & 8.9 & ૪.६ & y. & $y . y$ & 9.9 & $-0 . \gamma$ & 9.0 \\
\hline श्रीलडका & y.o & $\gamma . y$ & ३.६ & ३.३ & २.३ & $-\gamma . \xi$ & $y . \xi$ \\
\hline अफगानिस्तान & 9.0 & २.२ & २.६ & 9.2 & ३.९ & -4.0 & ४. \\
\hline चीन & $\xi . ९$ & $\xi . \zeta$ & $\xi . ९$ & $\xi . ७$ & $\xi .9$ & 9.9 & द. २ \\
\hline
\end{tabular}

स्रोत : अन्तर्राष्ट्रिय मुद्रा कोष, २०२०

विश्व बैंकका अनुसार कोभिड - 99 को महामारीबाट बच्न अँगालिएका लकडाउन लगायतका उपायहरुले गर्दा नेपालको अर्थतन्त्र सन् २०२० मा ०.२ प्रतिशतले मात्रै वृद्धि हुने प्रक्षेपण छ। यस रोगले गरिब, कमजोर वर्ग तथा अनौपचारिक क्षेत्रमा काम गर्नेलाई असर गरेकोले गरिबी बढ़ने अनुमान छ (World Bank, 2020 Fall, p. 123) त्यस्तै, एशियाली विकास बैंकका अनुसार सन् २०२० मा नेपालको आर्थिक वृद्धिदर २.३ प्रतिशत हुने अनुमान छ (Asian Development Bank, 2020, p. 1) एसियाली विकास बैंकले गरेको अनुमान र केन्द्रीय तथ्याङक विभागको अनुमान मिल्दो देखिन्छ । ओभा (२०७७) का अनुसार सन् २०२० मा रोगका कारण विश्व व्यापारमा कण्डै साढे $९$ प्रतिशतको हाराहारीमा सङकुचन आउने विश्व व्यापार सझ्गठनले अनुमान गरेको छ।
यस रोगको महामारीको कारण सिर्जित असहज परि स्थितिले नेपालको अर्थतन्त्रमा पनि गम्भीर असर परेको छ। आर्थिक सर्वेक्षण २०७६/७७ अनुसार आर्थिक वर्ष २०७३/७४ मा द. २ प्रतिशत, आर्थिक वर्ष २०७४/७४ मा ६.७ प्रतिशत र आर्थिक वर्ष २०७५/७६ मा ७ प्रतिशत आर्थिक वृद्धि हासिल भएकोमा आर्थिक वर्ष २०७६/७७ मा २. २६ प्रतिशतमा सीमित हुने प्रारम्भिक अनुमान छ (नेपाल सरकार, २०७६/७७, पृ.१२)

कोरोना महामारीले सबै भन्दा बढी पर्यटन क्षेत्रलाई असर गरेको छ। आर्थिक वर्ष २०७६/७७ को पहिलो द महिनामा १३.द प्रतिशतले पर्यटक आगमनमा कमी आएकोमा पछिल्लो $\vee$ महिनामा ९९.९ प्रतिशतले कमी आएको छ र समग्रमा आर्थिक वर्ष २०७६/७७ मा ३७.७ प्रतिशतले पर्यटक आगमन घटेको छ (नेपाल सरकार, अर्थ बुलेटिन, २०७७, प्.१७) 
आर्थिक सर्वेक्षण २०७६/७७ अनुसार आर्थिक वर्ष २०७६/७७ मा पर्यटन क्षेत्रको वृद्धिदर १६.३ प्रतिशतले ऋणात्मक रहने अनुमान छ। यसैगरी यातायात, भण्डारण तथा संचार, उत्पादनमूलक उद्योग, खानी तथा उत्वनन र निर्माण क्षेत्रको वृद्धिदर समेत ऋणात्मक हुने अनुमान छ। आर्थिक वर्ष २०७६/७७ मा कोरोना महामारीबाट प्रतिकूल प्रभाव नपरेका मत्स्यपालन, विद्युत, ग्यास तथा पानी, स्वास्थ्य तथा सामाजिक कार्य र सार्वजनिक प्रशासन तथा रक्षा क्षेत्रको वृद्धिदर गत आर्थिक वर्ष भन्दा उच्च रहने र बाँकी क्षेत्रहरुको वृद्धिदर गत वर्ष भन्दा न्यून रहने अनुमान छ। (नेपाल सरकार २०७६/७७, प्.१७७)

राष्ट्रिय योजना आयोगले राष्ट्रिय विकास समस्या समाधान समितिको $\zeta_{5}$ औं बैठकमा प्रस्तुत कार्यपत्रमा कोभिड - १९ महामारीले आर्थिक वर्ष २०७६/७७ मा कृषि क्षेत्रतर्फ रु. 90 अर्ब र गैरकृषि क्षेत्रतर्फ रु. १४६ अर्ब गरी अर्थतन्त्रमा रु. 9 खर्ब ६६ अर्ब बराबरको
क्षति भएको अनुमान छ। यसका साथै आर्थिक वर्ष २०७६/७७ मा आर्थिक वृद्धिदर ०.६ प्रतिशत मात्रै हुने तथा कोभिड - 99 को प्रभावले थलिएको नेपालको अर्थतन्त्र पुरानै अवस्थामा ल्याउन रु. ६ खर्ब ६प अर्ब लाग्ने प्रक्षेपण छ। यसरी आर्थिक वृद्धिदरका सम्बन्धमा अन्तर्राष्ट्रिय आर्थिक संस्था र सरकारी निकायको प्रक्षेपण फरक फरक भए पनि सबै अध्ययनको निचोड यस रोगले नेपालको आर्थिक वृद्धिदरमा प्रतिकूल प्रभाव पारेको देखिन्छ।

\section{(ख) राजस्व सडकलनमा परेको प्रभाव}

आर्थिक वर्ष २०७६/७७ मा नेपाल सरकारले रु. ११ खर्व १२ अर्ब राजस्व सङकलन गर्ने लक्ष्य राखेकोमा रु. द खर्ब ४१ अर्ब राजस्व सङकलन भएको छ। आर्थिक वर्ष २०७६/७७ मा राजस्व सङकलनको अवस्था देहायबमोजिम रहेको छ :

तालिका ३ : आ.व. २०७६/७७ को वार्षिक राजस्व संकलनको विवरण

(रु. करोडमा)

\begin{tabular}{|c|c|c|c|c|}
\hline कर शीर्षक & $\begin{array}{l}\text { आ.व. २०७६/७७ } \\
\text { को वार्षिक लक्ष्य }\end{array}$ & $\begin{array}{c}\text { आ.व. } \\
\text { २०७५ /७६ को } \\
\text { सङ.कलन }\end{array}$ & $\begin{array}{c}\text { आ.व. } \\
\text { २०७६/७७ को } \\
\text { सङकलन }\end{array}$ & $\begin{array}{c}\text { गत वर्षको तुलनामा } \\
\text { वृद्धिदर प्रतिशत }\end{array}$ \\
\hline मूल्य अभिवृद्धि कर & ३9४०१ & २४१६१ & २२૪०७ & $-\vartheta$ \\
\hline आयकर & २५०३И & १९४२६ & २१९६९ & १३ \\
\hline भन्सार महसुल & २१३२० & १४ূџ३७ & १३७९९ & -99 \\
\hline अन्त:शुल्क & १६९९ร & १२१६६ & १००६२ & -৭৩ \\
\hline शिक्षा सेवा शुल्क & 994 & 905 & $y=$ & $-૪ \xi$ \\
\hline अन्य कर & ২০૪৩ & १૪๘३ & १७१० & $9 y$ \\
\hline कर राजस्व जम्मा & १००९१६ & ७२९०३ & ৩০০০Y & $-\gamma$ \\
\hline गैर कर राजस्व जम्मा & १०२६७ & 90049 & ९३७३ & $-७$ \\
\hline कुल राजस्व & १९९२०३ & इ२९६२ & ৩९३७६ & $-\gamma$ \\
\hline अन्य प्राप्ति & - & 9008 & ૪७Y Б & ३७४ \\
\hline जम्मा राजस्व / प्राप्ति & १११२०३ & こ३९६६ & こ૪१३६ & 0.20 \\
\hline
\end{tabular}

स्रोत : अर्थ मन्त्रालय, २०७७ 
कोभिड - १९ को कारण राजस्व सङकलन प्रभावित हुँदा लक्ष्यअनुसार राजस्व सङकलन हुन नसकेको पाइन्छ। संघले प्रदेश तथा स्थानीय तहमा सर्त रुपमा पठाएको रकम खर्च नभई संघको संचित कोषमा फिर्ता हुँदा अन्य प्राप्ति भने गत आर्थिक वर्षको भन्दा धेरै देखिएको छ। यसले गर्दा गत वर्षको भन्दा राजस्व सङकलन थोरै बढे पनि वार्षिक लक्ष्यको तुलनामा ७६ प्रतिशत मात्र राजस्व उठेको छ। आर्थिक वर्ष २०७६/७७ मा कोभिडका कारण गत वर्षको भन्दा आयातमा १६ प्रतिशतले कमी आएकाले भन्सार विन्दुमा सङकलन हुने राजस्वमा ठूलो गिरावट आएको छ। त्यसरी नै कोरोना रोगको सङक्रमण रोकथाम तथा नियन्त्रण र उपचारका लागि आवश्यक पर्ने औषधि, स्वास्थ्य सामग्री र उपकरण, मास्क, सेनिटाइजर लगायतमा भन्सार महसुल र अन्य कर छुट दिएका कारण भन्सार बिन्दुमा सङकलन हुने राजस्वमा कमी आएको छ।

कोभिड - १९ को रोकथाम तथा नियन्त्रणका लागि अन्तर्राष्ट्रिय सीमा नाका बन्द गर्ने तथा देश भित्र
लकडाउन भएका कारण आयात, निर्यात, उत्पादन, विक्री वितरण घट्न गएको पाइन्छ। लकडाउन विस्तारै खुकुलो हुँदै गए पनि सबै श्रमिक तथा कर्मचारीहरु काममा उपस्थित नहुँदा र उद्योग व्यवसाय पूर्ण रुपमा सन्चालन हुन नसक्दा व्यवसायिक कारोवारबाट सङकलन हुने मूल्य अभिवृद्धि कर, अन्तशुल्क जस्ता अप्रत्यक्ष कर र आय तथा मुनाफामा आधारित आयकर समेत प्रभावित बन्न पुगेको छ। लकडाउनका कारण करदाताले नियमित रुपमा बुभाउनुपर्ने कर विवरण, आयविवरण र विवरणअनुसारको कर समयमै नबुभाएका कारण राजस्व सङकलन प्रभावित भएको छ, । लकडाउनको समयमा अत्यावश्यक बाहेकका सार्वजनिक सेवा प्रवाह ठप्प रहँदा गैरकर असुलीमा समेत नकारात्मक असर परेको छ।

\section{(ग) सार्बजनिक खर्चमा प्रभाव}

आर्थिक वर्ष २०७६/७७ मा कुल संघीय खर्च रु. १० खर्ब $९ ३$ अर्ब $y y$ करोड भएको छ। विनियोजनको तुलनामा खर्च ७१. ३ प्रतिशत भएको छ।

\section{तालिका $४$ : विनियोजन ₹ खर्चको अवस्था}

(रु. करोडमा)

\begin{tabular}{|c|c|c|c|c|c|}
\hline \multirow[b]{2}{*}{ विवरण } & \multirow[b]{2}{*}{$\begin{array}{l}\text { आ. व. २०७६/७७ } \\
\text { मा कुल विनियोजन }\end{array}$} & \multicolumn{2}{|c|}{ खर्च } & \multirow[b]{2}{*}{$\begin{array}{c}\text { वृद्धि } \\
\text { प्रतिशत }\end{array}$} & \multirow{2}{*}{$\begin{array}{l}\text { आ.व. २०७६/७७ मा } \\
\text { विनियोजनका तुलनामा } \\
\text { खर्च प्रतिशत }\end{array}$} \\
\hline & & $\begin{array}{c}\text { आ.व. } \\
\text { २०७४/७६ }\end{array}$ & $\begin{array}{c}\text { आ.व. } \\
\text { २०७६/७७ }\end{array}$ & & \\
\hline चालु खर्च & ९у ७९० & ७৭६૪२ & ৩૬ ૪৭४ & $\rho . y$ & Б9.९ \\
\hline पूरजीगत खर्च & ૪০૬০০ & २४१४६ & 99949 & -२०.७ & $\gamma \xi . \rho$ \\
\hline वित्तीय व्यवस्था & १६७६६ & qy२ช & ৭৭७६९ & -२२.७ & ৩০.२ \\
\hline कुल जम्मा & १५३२९६ & 9990४६ & 909 ३ूप & -9.4 & ७१.३ \\
\hline
\end{tabular}

स्रोत : महालेखा नियन्त्रक कार्यालय, २०७७

कोभिड - $9 ९$ को सङक्रमण रोकथाम तथा नियन्त्रणका लागि अवलम्बन गरिएका उपायका कारण आर्थिक वर्ष २०७६/७७ को अन्तिम चौमासिकमा लामो समयसम्म लकडाउन हुँदा पुँजीगत खर्च कम हुनाका साथै चालु
खर्चका कार्यकम सळ्चालनमा समेत अवरोध आएकोले लक्ष्य अनुसार खर्च हुन सकेको छैन् यस रोगका कारण स्वास्थ्य क्षेत्रमा बढी खर्च गर्नुपरेको तथा प्रदेश र स्थानीय तहलाई अनुदान दिनुपरेको कारण चालुतर्फ 
खर्च बढेको छ। आर्थिक वर्ष २०७६/७७ को तेस्रो चौमासिकमा यस रोगको रोकथामका लागि चालिएको कदमबाट विकास आयोजना पूर्ण रुपमा सन्चालन हुन नसक्दा पुँजीगत खर्च भने न्यून भएको छ।

\section{(घ) वैदेशिक सहायता परिचालनमा प्रभाव}

आर्थिक वर्ष २०७६/७७ को बजेटमा वैदेशिक अनुदान रु. पै अर्ब ९९ करोड र वैदेशिक ऋण रु. २ खर्ब ९६ अर्ब द३ करोड गरी रु. ३ खर्ब पू६ अर्ब दर करोड
वैदेशिक सहायता परिचालन गर्ने लक्ष्य थियो। यसमा अनुदान रु. ३० अर्ब १० करोड र ऋण रु. १ खर्ब द९ अर्ब ७द करोड गरी जम्मा रु. $२$ खर्ब 99 अर्ब द६ करोड बराबरको वैदेशिक सहायता प्रतिबद्धता प्राप्त भएको छ। परिचालनतर्फ अनुदान रु. २३ अर्ब २२ करोड र ऋण रु.१ खर्ब १६ अर्ब ९६ करोड गरी रु. १ खर्ब $४ २$ अर्ब १६ करोड बराबरको वैदेशिक सहायता प्राप्त गरेको छ।

तालिका $y$ : आ.व. २०७६/७७ मा विकास सहायता परिचालनको लक्ष्य, प्रतिवद्धता र प्राप्ति

(रु. करोडमा)

\begin{tabular}{|c|c|c|c|}
\hline सहायता शीर्षक & परिचालन लक्ष्य & प्रतिबद्धता & प्राप्ति \\
\hline अनुदान & yง ९९ & ३०१० & २३२२ \\
\hline ऋण & २९Бこ३ & १६९७६ & १९६९६ \\
\hline जम्मा & ३प६६र & २१९६द & १४२१६ \\
\hline
\end{tabular}

स्रोत : महालेखा नियन्त्रक कार्यालय, २०७७

यस अनुसार बजेटमा विकास सहायता परिचालन गर्ने लक्ष्यअनुसार प्रतिबद्धता र प्राप्ति भएको पाइँदैन् आर्थिक वर्ष २०७६/७७ मा कुल वैदेशिक सहायताको लक्ष्यमा ६२ प्रतिशत प्रतिबद्धता र ४० मात्र प्रतिशत प्राप्ति भएको छ। यस रोगका कारण विश्वका सबै देशको अर्थतन्त्रमा गम्भीर असर परेकाले अनुदानमा कमी हुने देखिन्छ भने ऋणको मात्रा बढ़दै जाने देखिन्छ ।

\section{(ङ) सार्वजनिक ऋणमा प्रभाव}

आर्थिक वर्ष २०७६/७७ मा नेपाल सरकारले रु. १ खर्ब ९४ अर्ब ६ ४ करोड आन्तरिक ऋण परिचालन गरेको छ,
भने रु. ३४ अर्ब ४० करोड सावा भुक्तानी गरेको छ। बाह्रय ऋण रु. $१$ खर्ब १६ अर्ब ९६ करोड परिचालन गरेको छ। २०७७ असार मसान्तसम्म नेपाल सरकारले कुल तिर्न बाँकी आन्तरिक ऋण रु. ६ खर्ब १३ अर्ब २१ करोड र बाह्रय ऋण $द$ खर्ब $y$ अर्ब $द$ ३ करोड गरी कुल तिर्न बाँकी सरकारी ऋण रु. १४ खर्ब १९ अर्ब पुगेको छ। कुल गार्हस्थ्य उत्पादनसंग यसको अनुपात ३७७७ प्रतिशत रहेको छ।

तालिका ६ : सार्वजनिक ऋणको स्थिति

\begin{tabular}{|c|c|c|c|c|c|c|}
\hline \multirow[t]{2}{*}{ शीर्षक } & \multicolumn{2}{|l|}{ रकम } & करोडमा & \multicolumn{3}{|c|}{ कुल गार्हस्थ्य उत्पादनसंगको अनुपात } \\
\hline & ২০৩४/৩४ & २०७४/७६ & २০७६/७७ & २০७૪/৩४ & २०७४/७६ & २०७६/७७ \\
\hline तिर्न बाँकी आन्तरिक ऋण & ३९०९० & ชy२९७ & ६१३२१ & १२.द & १३.१ & १६.३ \\
\hline तिर्न बाँकी बाह्रय ऋण & पूरू३ू & प९४६१ & ऽОУこ३ & १७.३ & q७.? & २१. ४ \\
\hline तिर्न बाँकी कुल ऋण & ९१६२प & ৭०४७Y द & q४9९०४ & ३०. 9 & ३०.३ & ३७.৩ \\
\hline
\end{tabular}

स्रोत : महालेखा नियन्त्रक कार्यालय, २०७७ 
यस रोगका कारण राजस्व परिचालनमा असर परेको तथा स्वास्थ्य सुरक्षाका लागि खर्च गर्नुपर्ने भएकाले आन्तरिक तथा बाह्रय ऋण परिचालन अभ बढ़ने देखिन्छ ।

\section{(च) मौद्रिक क्षेत्रमा परेको प्रभाव}

कोभिड - १९ अघिको तुलनामा बैंक तथा वित्तीय संस्थाहरुमा बचत परिचालनमा वृद्धि भएको तर कर्जा लगानीमा भने कमी आएकोले बैंक तथा वित्तीय संस्थामा अधिक तरलताको अवस्था आएको छ। कर्जाको माग धेरै नभएकोले बैंक तथा वित्तीय संस्थाले व्याजदर घटाएका छन् कर्जाको व्याजदर घटेपछि, निक्षेपको व्याजदर पनि घटेको छ। यसले गर्दा निक्षेप जम्मा गर्ने सर्वसाधारणलाई बैंकले दिने व्याजको दरमा कमी भएको छ भने कर्जा लिनेलाई विगतको तुलनामा सस्तो पर्न गएको छ।

बन्जाडे (२०७७) को विचार अनुसार निक्षेपको व्याजदर कम हुँदा निक्षेपकर्ता बचत गर्न निरुत्साहित हुन्छन् बैंकमा बचत नगर्दा सर्वसाधारणको हातमा नगद धेरै हुन्छ। नगद धेरै हुँदा अनुत्पादक (अनावश्यक) क्षेत्रमा बढी खर्च हुन्छ । अनौपचारिक क्षेत्रमा नगद प्रवाह हुन्छ। जसले अर्थतन्त्रलाई फाइदा पुत्दैन।

\section{(छ) मुद्रास्फितीमा परेको प्रभाव}

नेपाल राष्ट्र बैंककाअनुसार आर्थिक वर्ष २०७६/७७ मा वार्षिक औसत उपभोक्ता मुद्रास्फिती ६.१५ प्रतिशत रहेको छ। आर्थिक वर्ष २०७४/७६ मा यस्तो मुद्रास्फिती $४$.६ $४$ प्रतिशत रहेको थियो। चालु आर्थिक वर्ष २०७७/७६ को मंसिरमा उपभोक्ता मुद्रास्फिती २.९३ प्रतिशत रहेको छ (नेपाल राष्ट्र बैंक, २०७७ पुष, प.9) आन्तरिक मागमा कमी आएको, वस्तुको आपर्ति धेरै प्रभावित नभएको, कषि उत्पादनमा कोभिड - १९ बाट प्रभावित नभएको र आन्तरिक उत्पादनले बजार पाउँदा पछिल्ला दिनमा मुद्रास्फितीमा सुधार भएको पाइन्छ।

\section{(ज) बाहय क्षेत्रमा परेको प्रभाव}

कोभिड - १९ को कारण आर्थिक वर्ष २०७६/७७ मा अर्थतन्त्रमा प्रतिकल असर परेको भए तापनि बाह्य क्षेत्रका अधिकांश परिसचकहरु सन्तोषजनक रहेका छन् यस रोगले नेपालको बाह्रय क्षेत्रमा सकारात्मक प्रभाव परेको देखिन्छ ।

तालिका ७ : बाहय क्षेत्रका परिसूचकहरु

(रु. करोडमा)

\begin{tabular}{|c|c|c|}
\hline परिसूचक & २०७४/৩६ & २০৩६/৩৩ \\
\hline आयात & १४qБ४० & १९९६६० \\
\hline निर्यात & ९७९० & ९७७१ \\
\hline व्यापार घाटा & १३२१૪० & 909909 \\
\hline विप्रेषण आप्रवाह & ๘७९३০ & ¿७४০३ \\
\hline प्रत्यक्ष वैदेशिक लगानी & १६०६ & q९ช \\
\hline चालु खाता घाटा & २६प३६ & ३२०६ \\
\hline शोधनान्तर स्थिति & -६७૪০ & २५२४१ \\
\hline विदेशी मुद्रा संचिति & १०३५९२ & q४०१६૪ \\
\hline
\end{tabular}

स्रोत : नेपाल राष्ट्र बैंक, २०७७

सरकारले लक डाउन लागु गरेपछि, आवश्यक वस्तुबाहेक आयात कम गरेकाले व्यापार घाटामा उल्लेख्य सुधार आएको छ। विप्रेषण आप्रवाहमा खासै कमी आएको छैन् कोभिड - $9 ९$ का कारण विदेश जानेको कमी हुनुका साथै स्वदेश फर्कने भए तापनि अनौपचारिक आयातमा कमी भई कारोवार घटेको ₹ औपचारिक माध्यमबाट रकम नेपाल भित्रिएकाले विप्रेषण आप्रवाहमा खासै कमी नआएको पाइन्छ। शोधानान्तर बचत, विदेशी विनिमय सज्चिति बढेको छ। चालु खाता घाटा कम हुदै गएको छ। यसै गरी नेपाल राष्ट्र बैड़को चालु आर्थिक वर्ष २०७७/७६ को पाँच महिनामा व्यापार घाटा गत वर्षको सोही अवधिको तुलनामा १०.९ प्रतिशतले घटी रु. $४$ खर्ब $१ ६$ अर्ब $\leftrightharpoons$ करोड पुगेको छ। चालु खाता घाटा रु. २१ अर्ब ३२ करोडले बचतमा रहेको छ। कुल विदेशी विनिमय सज्चिति रु. १४ खर्ब ७४ अर्ब ३४ करोड पुगेको छ। शोधनान्तर स्थिति रु. १ खर्ब ६ अर्ब 
४५ करोडले बचतमा रहेको छ। (नेपाल राष्ट्र बैंक, २०७७ पुष, पृ. २ र ३)

\section{(भ) पूँजीबजारमा परेको प्रभाव}

नेपाल स्टक एक्सचेन्ज लिमिटेड (नेप्से) का अनुसार २०७६ असार मसान्तमा १२५९ विन्दु रहेको नेप्से सूचकांक २०७७ असारमा १३६२.४ विन्दु पुगेको छ। २०७७ पुष मसान्तमा २२६६.५ विन्दु पुगेको छ (Nepal Stock Exchange Limited, 2077) अर्थतन्त्रका अन्य क्षेत्रमा गतिविधि सुस्त भएकोले लगानीकर्ताले सेयर बजारलाई आकर्षक लगानीको क्षेत्रका रुपमा लिएको पाइन्छ। लकडाउनको अवधिमा बन्द भएको नेपालको सेयर बजार खुलेपश्चात् सुधार हुँदै गएको पाइन्छ। अनलाइन कारोवार प्रणाली, बैंकिड क्षेत्रमा पर्याप्त तरलता, व्याजदरमा कमी र लगानीका अन्य क्षेत्रहरु शिथिल रहेकोले कोभिड - १९ को विषय परिस्थितिमा समेत सेयर सूचकांक र कारोवार बढेको पाइन्छ।

\section{(ज) गरिबी र रोजगारीमा परेको असर}

कोभिड - १९ ले गरिबी र बेरोजगारी बढाएको विभिन्न अध्ययनले अनुमान गरेका छन् विश्व बैंकले कोरोना भाइरसका कारण विश्वमा $\sqsubset$ करोड $ॅ ०$ लाखदेखि ११ करोड पू० लाखसम्म गरिबी बढ़ने प्रक्षेपण गरेको छ। यसमा आधा दक्षिण एशियाका जनता छन् कृषि क्षेत्रमा काम गर्ने भन्दा सहरी क्षेत्रका र शिक्षित व्यक्तिमा गरिबी बढेको तथा यस रोगले आय असमानता र समावेशी आर्थिक वृद्धिमा चुनौती थपेको छ (World Bank, 2020, p. p. 5) विश्वका मुलुक लकडाउनको अवस्थामा रहादा करिब ९४ प्रतिशत कार्यस्थल बन्द रहेका छन् र यसले कामदार पूर्ण वा आंशिक रोजगारी कटौतीको सिकार भएका छन् (ILO, 2020, p. 1)

कोभिड - १९ को संकमण नियन्त्रणको लागि अवलम्बन गरिएको लकडाउन, सामाजिक दूरी लगायतले रोजगारीमा ठूलो प्रभाव पारेको छ । अनौपचारिक
क्षेत्रतर्फ अधिकांश कामदार/कर्मचारीले रोजगारी गमाउन पुगेको देखिन्छ। यस महामारीले विश्व आर्थिक गतिविधिमा सुस्तता आएसंगै वैदेशिक रोजगारीका अवसरहरु गुम्ने, तलब लगायतका सुविधा कटौती हुने तथा वैदेशिक रोजगारीप्रति लगाव कम हुन सक्ने देखिन्छ। (आर्थिक सर्वेक्षण २०७६/७७, पृ ११७)

वैदेशिक रोजगारीमा भएकाहरुमध्ये ठूलो संख्याले रोजगारी गुमाएका छन् र उनीहरु स्वदेश फर्कने कम जारी छ। कोभिड - १९ को प्रभावस्वरुप २०७७ असार मसान्तसम्म आन्तरिक रुपमा ९ लाख २४ हजार जनाले रोजगारी गुमाएको अनुमान छ भने विदेशमा रोजगारी गुमाउने नेपालीहरुको अनुमानित संख्या ६ लाख ४० हजार रहेको छ। १२ लाख नेपाली गरिबीको रेखामुनी पुगेका छन् (राष्ट्रिय योजना आयोग, २०७७, पृ. २७)

नेपालमा बेरोजगारी दर ११ प्रतिशत रहेको, हरेक वर्ष श्रमबजारमा करिब $y$ लाख श्रमशक्ति थपिने गरेको र मुलुक भित्र पर्याप्त रोजगारीको अवसर नपाएर ४७ लाख ९२ हजार वैदेशिक रोजगारीमा गएको अवस्थामा (नेपाल २०७६/७७, पृ.७१) कोभिड - १९ ले गर्दा अधिकांशले रोजगारी र स्वरोजगारी गुमाउन पुगेका छन् ।

आर्थिक वर्ष २०७६/७७ मा वैदेशिक रोजगारीमा जान नयाँ श्रम स्वीकति लिने नेपाली कामदारको संख्या २०. $५$ प्रतिशतले घटेर $१$ लाख ९३ हजार ९ सय ४५ रहेको छ (अर्थ मत्त्रालय, २०७७, प्.१६) चालु आर्थिक वर्ष २०७७/७६ को पहिलो पाँच महिनाका अवधिमा वैदेशिक रोजगारीका लागि अन्तिम श्रम स्वीकृति लिने नेपालीको संख्या ७७.९ प्रतिशतले कमी आएको छ। (नेपाल राष्ट्र बैंक, २०७७ पुष, प्.३)

युएनडिपीले गरेको अध्ययन अनुसार नेपालमा लकडाउनका कारण ३१.द प्रतिशत कामदारले रोजगारी गुमाएका छन् रोजगारी गुमाउनेमा पुरुष भन्दा महिला बढी छन् लघु, साना तथा मकौला उद्योगमा यस रोगले बढी असर गरेको छ। (UNDP, 2020, p. 14) 
नेपाल राष्ट्र बैंकले कोभिड - १९ ले अर्थतन्त्रमा पारेको प्रभाव सम्बन्धमा लकडाउनको समयमा र सो पश्चात् गरी २ पटक सर्वेक्षण गरेको छ। २०७७ असारमा गरेको अध्ययनअनुसार यस महामारी अगाडिको तुलनामा लकडाउनको समयमा पूर्ण रुपमा सळ्चालनमा रहेका उद्योग व्यवसाय ४.० प्रतिशत थिए भने आंशिक रुपमा सज्चालनमा रहेका उद्योग व्यवसाय ३५.० प्रतिशत थिए । ६१.० प्रतिशत उद्योग व्यवसाय पूर्णरुपमा बन्द रहेका थिए । कोभिड महामारी अगाडिको तुलनामा उद्योग व्यवसायहरुले ७७. $y$ प्रतिशत रोजगारी प्रदान गरेका थिए अर्थात् २२.द प्रतिशत कर्मचारी कटौती गरेका थिए। १६. २ प्रतिशत तलब कटौती गरेका थिए। (नेपाल राष्ट्र बैंक, २०७७ असार, पृ.१ र २)

नेपाल राष्ट्र बैंकले २०७७ मंसिरमा गरेको अध्ययन अनुसार कोभिड - १९ नियन्त्रणका मापदण्ड खुकुलो बनाउँदै लगेका कारण उद्योग व्यवसाय सज्चालन, उत्पादन र व्यावसायिक कारोवारमा वृद्धि हुँदै गएको छ। यस महामारी अगाडिको तुलनामा $ू \gamma$ प्रतिशत उद्योग व्यवसाय पूर्ण रुपमा सज्चालन भएका छन् भने ९.१ प्रतिशत उद्योग व्यवसाय अभै सञ्चालनमा आउन सकेका छैनन् यस महामारी अगाडिको तुलनामा उद्योग व्यवसायहरुले ५७.५ प्रतिशत रोजगारी प्रदान गरेका छन् (नेपाल राष्ट्र बैंक, २०७७ मंसिर, पृ. २ र y) । कोभिड पूर्वको अवस्थामा उद्योग व्यवसाय सञ्चालन हुन सकेका छैनन्

\section{कोभिड - १९ को सडक्रमण रोकथाम तथा नियन्त्रण र आर्थिक पुनरुत्थानका प्रयास}

कोभिड - १९ को सङक्कमण रोकथाम तथा नियन्त्रणका लागि सङघ, प्रदेश र स्थानीय तहका साथै निजी क्षेत्रबाट समेत कामहरु भएको छ। नेपाल सरकारले यस महामारीको सङक्रमण रोकथाम तथा नियन्त्रण गर्न उपप्रधानमन्त्री तथा रक्षामन्त्रीको संयोजकत्वमा कोभिड - १९ रोकथाम तथा नियन्त्रण उच्चस्तरीय समिति गठन गरेको थियो । पछि, उक्त समिति भड्न गरी उपप्रधानमत्त्रीको संयोजकत्वमा कोभिड सङकट
व्यवस्थापन सख्चालन केन्द्र निर्देशक समिति गठन भई काम भइरहेको छ। यसले केन्द्रीय, प्रादेशिक र स्थानीय तहसम्म निजामती, सुरक्षा निकाय र सबै सम्बद्ध निकायको सहभागितामा यस रोगको भाइरस विरुद्ध समन्वयात्मक रुपमा प्रतिकार्य सन्चालन गरेको छ । मुख्य सचिवको संयोजकत्वमा सुरक्षा निकायका प्रमुखहरु समेत संलग्न सहजीकरण समिति छ।

नेपाल सरकारको सचिवको संयोजकत्वमा कोभिड सङकट ब्यवस्थापन सञ्चालन केन्द्र (CCMC) सज्चालनमा छ। यसले व्यवस्थापकीय कार्य गर्ने गई । प्रत्येक प्रदेशमा मुख्यमत्त्रीको संयोजकत्वमा प्रदेश कोभिड सडकट व्यवस्थापन सळ्चालन केन्द्र, प्रमुख जिल्ला अधिकारीको संयोजकत्वमा जिल्ला कोभिड सङकट ब्यवस्थापन सन्चालन केन्द्र र पालिका प्रमुख/अध्यक्षको संयोजकत्वमा पालिका कोभिड सड् कट यवस्थापन सळ्चालन केन्द्र सन्चालनमा छ। यस रोगको संकमण रोकथाम, नियन्त्रण, उपचार तथा राहतको लागि स्रोत व्यवस्थापन गर्न कोरोना रोकथाम, नियन्त्रण र उपचार कोष स्थापना भएको छ । यस कोषबाट सड्घ, प्रदेश र स्थानीय तहमा क्वारेन्टाइन निर्माण, स्वास्थ्य पूर्वाधार र उपकरण व्यवस्था लगायतका कामहरु भइरहेको छन्।

नेपाल सरकारको वार्षिक नीति तथा कार्यकममा नेपाललाई कोभिड -१९ महामारीमुक्त देश बनाउनु सरकारको पहिलो प्राथमिकता भएको उल्लेख छ (नेपाल सरकार, २०७७, पृ.१९) । आर्थिक वर्ष २०७७/७६ को बजेटले यो रोग लगायत सबै प्रकारका स्वास्थ्य जोखिमबाट नागरिकलाई सुरक्षित राख्न र गुणस्तरीय स्वास्थ्य सेवा सर्वसुलभ बनाउन स्वास्थ्य सेवाको दायरा विस्तार, स्वास्थ्य पूर्वाधार निर्माण तथा स्तरोन्नति र स्वास्थ्य जनशक्ति विकास गर्ने, कोरोना भाइरस संक्रमणको रोकथाम तथा नियन्त्रणका लागि चालिएका कदमबाट टुटेको उत्पादन ₹ आपूर्ति शृडखलालाई पुनर्स्थापना गर्दे कृषि, उद्योग, पर्यटन, निर्माण लगायत प्रभावित व्यवसायको पुनरुत्थान गर्ने कुरालाई 
प्राथमिकता दिएको छ। बजेटमा स्वास्थ्य क्षेत्रको बजेट करिब एक तिहाई वृद्धि गरी रु.९० अर्ब ७० करोड पुगेको छ। मुलुकभरका अस्पतालहरुको पूर्वाधार विकासमा उच्च प्राथमिकता दिई बजेट विनियोजन भएको छ। (नेपाल सरकार, २०७७/७६, पृ.६ र १४)

आर्थिक वर्ष २०७७/७६ को मौद्रिक नीतिले कोभिड-१९ बाट प्रभावित अर्थतन्त्रको पुनरुत्थानमा जोड दिएको छ। बजेटमा व्यवस्था भएबमोजिम स्थापना हुने रु. पू० अर्बको कोष परिचालन मार्फत यो रोग प्रभावित व्यवसायको सन्चालन एवम् निरन्तरता, श्रमिक तथा कर्मचारीको पारिश्रमिक भुक्तानी ₹ अति प्रभावित क्षेत्रका रोजगारी गुम्नेहरुलाई उद्यमशीलता विकासको अवसर दिन बैंक तथा वित्तीय संस्थाहरुबाट $y$ प्रतिशत ब्याजमा कर्जा उपलब्ध गराउने व्यवस्था छ। यस रोगबाट प्रभावित भएको पेशा/व्यवसायमा प्रवाह भएका कर्जाको सावाको किस्ता र ब्याज रकम भुक्तानी गर्ने अवधि बढेको छ। यस रोगको सङकटबाट अति प्रभावित हवाई उड्डयन व्यवसाय, यातायात, होटल, रेस्टुरेन्ट लगायतका पर्यटन क्षेत्रका उद्यम-व्यवसाय पुनरुत्थानका लागि चालु पुाजी कर्जा, सहुलियतपूर्ण कर्जा र पुनर्कर्जा प्रवाहमा प्राथमिकता दिएको छ।

विश्वव्यापी रुपमा फैलिएको कोभिड-१९ को रोकथाम, नियन्त्रण र उपचारका अतिरिक्त सङक्रमणको प्रभाव न्यूनीकरण गर्न अबलम्बन गरिएका क्रियाकलापबाट सिर्जना भएको परिस्थितिसंग सामना गर्न राहत, सहुलियत, छुट एवं अन्य विभिन्न वित्तीय तथा मौद्रिक उपायहरु अवलम्बन भएको अर्थ मत्त्रालयबाट प्रकाशित वार्षिक प्रगति मूल्यांकनमा उल्लेख छ। (नेपाल सरकार, २०७७ मंसिर, पृ. ७७)

कोभिड-१९ को सङक्रमण जोखिम न्यूनीकरणका लागि नेपाल सरकारले २०७६ चैत्र ११ देखि लकडाउनको घोषणा गरेपछि, २०७६ चैत्र १६ मा रोगको कारण प्रभावितहरुलाई प्रदान गरिने राहत, कर छुट तथा सुविधा सम्बन्धी प्रस्ताव नेपाल सरकार (मन्त्रिपरिषद्) बाट स्वीकृत भई कार्यान्वयनमा आएको थियो। त्यसैगरी
२०७७ वैशाख १४ मा दोस्रो चरणको राहत, कर छुट तथा सुविधा स्वीकृत भई कार्यान्वयनमा आएको थियो कोरोना प्रभावित घरेलु, साना तथा मकौला उद्योग, उत्पादनमूलक उद्योग, होटल, पर्यटन लगायतका क्षेत्रका उद्योग व्यवसायलाई $y$ प्रतिशतसम्म सहुलियत व्याजदरमा कर्जा उपलब्ध भएको छ। कोरोना प्रभावित व्यवसाय पुनरुत्थान गर्न रु. $२$ खर्ब सम्मको पुनर्कर्जा उपलब्ध गराउने व्यवस्था छ। सड्रठित क्षेत्रमा काम गर्ने श्रमिकको योगदानमा आधारित सामाजिक सुरक्षा कोषमा श्रमिक र रोजगारदाताका तर्फबाट गर्नुपर्ने २०७६ चैत्र महिनादेखि २०७७ असार मसान्तसम्मको योगदान वापत रु.१ अर्ब ३ करोड नेपाल सरकारबाट सामाजिक सुरक्षा कोषमा जम्मा भएको छ।

कोभिड-१९ कारण श्रमविहीन भएका र विदेशबाट फर्किएका श्रमिकलाई समेत समेट्ने गरी आर्थिक वर्ष २०७७/७६ मा थप १२ लाख नयाँ रोजगारी सिर्जना गर्न प्रधानमन्त्री रोजगार कार्यक्रम, सहुलियतपूर्ण कर्जा कार्यक्रम, साना किसान कर्जा कार्यक्रम, रोजगारी सहितको तालिम कार्यक्रम लगायतका अन्य कार्यक्रम सज्चालनमा छन् असंगठित क्षेत्रमा कार्यरत रही रोजगारी वा काम विहीन भएका श्रमिकलाई सार्वजनिक काममा लगाई काम वा श्रम गराउादा निजहरुलाई दैनिक ज्याला नगद वा खाद्यान्नका रुपमा उपलब्ध गराउने व्यवस्था छ।

वैदेशिक रोजगारीमा जानका लागि अनुमति लिई जान नपाएका व्यक्तिले सङक्रमणको जोखिम समाप्त भएपछि सहुलियतपूर्ण कर्जा लिई उद्योग व्यवसाय सन्चालन गर्न चाहेमा निवेदन दिएको सातदिन भित्र सहुलियतपूर्ण कर्जा उपलब्ध गराउने व्यवस्था छ। बैंक तथा वित्तीय संस्थाहरुले आफना ग्राहकलाई विद्युतीय माध्यमबाट सेवासुविधा दिए बापत कुनै प्रकारको थप शुल्क नलिने व्यवस्था भएको थियो। यस रोगका कारण प्रभावित भएका निर्माण, यातायात, आमसन्चार, चलचित्र क्षेत्रमा इजाजतपत्र तथा उपकरण नवीकरण दस्तुरमा छुट, बैक ग्यारेन्टीको म्याद थप गर्ने व्यवस्था भएको छ। 
कोभिड-१९ को उपचारलाई समेत सहयोग पुग्ने गरी सेवा विस्तार र स्तरोन्नति गर्न चाहने निजी स्वास्थ्य प्रदायक संस्थाहरुलाई प्रवाह गरिने कर्जालाई प्राथमिकता प्राप्त क्षेत्रअन्तर्गत समावेश गर्ने व्यवस्था भएको छ, अत्यावश्यक औषधि, स्वास्थ्य उपचारमा प्रयोग गरिने स्वास्थ्य सामाग्री तथा उपकरण एवं खाद्यान्न लगायतका दैनिक अत्यावश्यकीय वस्तुको पैठारी टि.टि. मार्फत् गर्दा हाल कायम रहेको ३० हजार अमेरिकी डलरको सीमा १ लाख पुगेको छ।

स्वास्थ्य तथा जनसंख्या मन्त्रालयले कोभिड-१९ को सङक्रमण, रोकथाम तथा नियन्त्रण र उपचारका लागि सूचीकृत गरेका स्वीकृत मापदण्डअनुसारको विभिन्न प्रकारका औषधि, स्वास्थ्य सामग्री र उपकरण पैठारी गर्दा लाग्ने सम्पर्ण महसुल छुटको व्यवस्था छ। स्वास्थ्य तथा जनसंख्या मन्त्रालयको सिफारिसमा स्वस्थ्य संस्थामा हस्तान्तरण गर्ने गरी विभिन्न संघसंस्था वा व्यक्तिले सहयोगस्वरुप उपलब्ध गराएका औषधि, स्वास्थ्य उपकरणमा लाग्ने सम्पूर्ण महसुल छुट भएको छ। फेस मास्क, सेनिटाइजर र सर्जिकल ग्लोभ्समा दरबन्दीबमोजिम लाग्ने महसुल छुट, इन्डक्सन चुल्होमा लाग्ने भन्सार महसुल घटेको छ। औषधि उत्पादन गर्ने उद्योगले स्यानिटाईजर उत्पादनका लागि आवश्यक पर्ने कच्चा पदार्थ इथानोल स्वदेशी उद्योगहरुबाट खरिद गरी स्यानिटाइजर उत्पादन गरेमा इथानोल खरिदमा लाग्ने अन्तःशुल्क छुट भएको छ।

उद्योगी तथा व्यवसायीहरुको आयात तथा निर्यातको ऋममा रहेको कन्टेनर तथा ट्रकमा लाग्ने डेमरेज तथा डिटेन्शन चार्ज नलाग्ने व्यवस्था भएको छ। कुनै व्यक्तिले आर्थिक वर्ष २०७६/७७ मा नेपाल सरकार, प्रदेश ₹ स्थानीय तहले स्थापना गरेको कोरोना सडक्रमण रोकथाम नियन्त्रण तथा उपचार कोषमा योगदान गरेको रकम उक्त वर्षको आय गणना गर्दा घटाउन पाउने गरी खर्च कट्टी गर्न दिने व्यवस्था छ। कोरोना सङक्रमणको जोखिम न्यनीकरण गर्न सरकारले घोषणा गरेको लकडाउनको अवधिमा करदाताले
भुक्तानी गर्नुपर्ने कर स्थगन गरेको छ।

कोभिड - १९ सङक्रमणको सार्वजनिक स्वास्थ्य सस्थामा परीक्षण तथा बिरामीको सम्पर्ण उपचार खर्च निशुल्क हुने व्यवस्था छ। बजेटबाट र कोरोना रोकथाम, नियन्त्रण तथा उपचार कोषबाट थप बजेट निकासा, रकमान्तर र प्रदेश तथा स्थानीय तहलाई वित्तीय हस्तान्तरण भएको छ। नेपाल सरकारका अस्पतालहरु र प्रादेशिक अस्पतालहरुमा मेशिन उपकरण खरिद, रिएजेन्ट, पिसिआर मेशिन र किट, बेड, मास्क, सेनिटाईजर सहित व्यक्तिगत सुरक्षा उपकरणहरु, आइसियु खरिद गर्न थप बजेट निकासा भएको छ। विभिन्न स्थानमा क्वारेन्टाइन निर्माण र सज्चालन खर्च, विदेशबाट उद्धार गरिएका नागरिकको उद्धार खर्च, क्वारेन्टाइनस्थलमा राखिएको अवधिको सम्पूर्ण खर्च सरकारले व्यहोरेको छ।

सङक्रमित बिरामीको अवस्था हेरी औषधि, खाने बस्ने खर्च, चिकित्सकको जोखिम भत्ता सहित प्रति बिरामी प्रतिदिन खर्च अस्पतालहरुलाई उपलब्ध भएको छ। यस रोगको उपचारमा अग्रपंक्तिमा संलग्न चिकित्सक, स्वास्थ्यकर्मी र प्रयोगशालामा काम गर्ने कर्मचारीलाई जोखिम भत्ता उपलब्ध गराउनुका साथै कोरोना लगायतका अन्य सङक्रामक रोग विरुद्ध कार्यरत सबै स्वास्थ्यकर्मीलाई रु.द लाखसम्मको निशुल्क स्वास्थ्य बिमाको व्यवस्था छ। रु. १ लाखसम्मको सामूहिक कोरोना बिमा गर्दा लाग्ने वार्षिक शुल्कमा सरकारले पू० प्रतिशत अनुदान दिने व्यवस्था छ।

गुणस्तरीय आधारभूत स्वास्थ्य सेवामा सबै नागरिकको पहूँच सुनिश्चित गर्न सबै स्थानीय तहमा $y$ देखि $9 y$ शय्यासम्मका आधारभत अस्पताल स्थापना गर्ने कार्य अगाडि बढेको छ। कोभिड -१९ को विरुद्ध भ्याक्सिन सेवा आपर्ति गर्ने सम्बन्धमा प्रकिया अगाडि बढेको छ। भारत सरकारले १० लाख डोज खोप उपलब्ध गराइसकेको छ। यस रोगको महामारी पश्चात् दात् निकायहरुले सामाजिक क्षेत्रमा लगानी बढाएका छन् स्थानीय तहले यस रोगको रोकथाम र नियन्त्रणमा चालेको कदम सराहनीय छ। 
कोभिड - १९ को रोकथाम तथा नियन्त्रण गर्न तथा अर्थतन्त्र चलायमान बनाउन सुभाव

कोभिड - १९ संकमण रोकथाम तथा नियन्त्रणका लागि सरकारी तथा निजी क्षेत्रबाट धेरै काम भएका छन् यद्यपि यसको रोकथाम तथा नियन्त्रणलाई प्रभावकारी बनाउन र अर्थतन्त्रलाई चलायमान बनाउन देहायका थप काम गर्नुपछ :

(क) स्वास्थ्य सुरक्षा मापदण्डको पालना र खोपको प्रयोग

कोभिड - १९ लाई नियन्त्रण गर्न स्वास्थ्य सुरक्षा सम्बन्धी उपाय सबै क्षेत्र र जनसमुदायमा अबलम्वन गराउन व्यापक जनचेतना फैलाउनुपई। यस रोगका विरुद्धको भ्याक्सिन खरिदका लागि सरकारले पहल गरिरहेकोमा समयमै यसको आपूर्ति गरी जनतालाई उपलब्ध गराउनुपछ। सके सबै जनतालाई नसके कम्तीमा आधा जनसंख्यालाई पुग्ने गरी नेपालमा खोप ल्याउन विश्व स्वास्थ्य सझुन लगायत अन्य दातृ निकायसंग समन्वय र सहकार्य गर्नुपछ। भारत सरकारले अनुदानस्वरुप उपलब्ध गराइसकेको र चीन सरकारले उपलब्ध गराउन लागेको खोपको उचित प्रयोग गर्नुपछ ।

\section{(ख) स्वास्थ्य पूर्वाधारको पर्याप्तता}

नेपालमा स्वास्थ्य पर्वाधारहरु अस्पताल, स्वास्थ्य चौकी, प्रयोगशाला, उपकरणका साथै डाक्टर, नर्स लगायतका स्वास्थ्य जनशक्ति न्यून छ। स्वास्थ्य पूर्वाधारको निर्माणलाई व्यवस्थित गर्दे उपकरण र जनशक्ति बढाएर जनताको जीवनस्तरमा सुधार गर्नुपई।

(ग) राहत, सहुलियत, छुट तथा पुनरुत्थानका कार्यकमको प्रभावकारी कार्यान्वयन

कोभिड-१९ को रोकथाम, नियन्त्रण र उपचारका अतिरिक्त सड्क्रमणको प्रभाव न्यूनीकरण गर्न अवलम्बन गरिएका राहत, सहुलियत, छुट एवं अन्य विभिन्न वित्तीय तथा मौद्रिक उपायहरुको प्रभावकारी
कार्यान्वयनमा जोड दिनुपछ । कोरोनाबाट प्रभावित उद्योग व्यवसायलाई राहत दिई शिथिल भएको आर्थिक क्रियाकलापलाई चलायमान बनाउन बजेट, मौद्रिक नीति मार्फत् ल्याइएका पुनरुत्थानका कार्यकमको समयमै कार्यान्वयन गरी उद्योग व्यवसायको पुनस्स्थापना र पुनसंरचनामा सहयोग गनुपछ।

\section{(घ) रोजगारी सिर्जना}

कोभिड - १९ को कारण धेरैको रोजगारी गुमेकोले नयाँ रोजगारी सिर्जना गर्न प्रधानमन्त्री रोजगार कार्यक्रम, सहुलियतपूर्ण कर्जा कार्यक्रम, साना किसान कर्जा कार्यक्रम, रोजगारी सहितको तालिम कार्यक्रम लगायतका कार्यक्रमको प्रभावकारी रुपमा कार्यान्वयन गर्नुपछ। वैदेशिक रोजगारीमा जाने नेपालीको संख्या कम हुँदै गएकाले नेपालको अर्थतन्त्रका खम्वाका रुपमा रहेका पर्यटन, ऊर्जा, कषि र पर्वाधार क्षेत्रमा लगानी गरी स्वदेशमै रोजगारी सिर्जना गर्नुपछ। यस रोगले स्वास्थ्य, शिक्षा र कृषि क्षेत्रमा लगानी बढाउन तथा स्वदेशमा रोजगारी सिर्जना गर्न पाठ सिकाएकाले यसलाई अवसरको रुपमा लिनुपछ।

\section{(ङ) सार्वजनिक खर्चको प्रभावकारी व्यवस्थापन}

कोभिड - १९ का कारण एकातिर राजस्व घट्ने र अन्य स्रोत साधनको पनि सीमितता हुने अर्कोतिर राज्यले ठूलो धनराशि खर्च गर्नु पर्ने भएकाले अनावश्यक खर्चमा नियन्त्रण गर्नुपई। चालु खर्चलाई बान्छित सीमामा राखी पुँजीगत खर्चलाई बढाउँदै जानुपई । विनियोजन कुशलता र कार्यान्वयन दक्षतामा तालमेल मिलाउनुपछ ।

\section{(च) सूचना प्रविधिको प्रयोगमा जोड}

कोभिड - १९ को सङकमणबाट बच्न सेवाप्रवाहमा सूचना प्रविधिको प्रयोगमा वृद्धि गर्नुपछ। सेवाप्रवाहको लागत घटाउन, सुरक्षित, छिटो छरितो र पारदर्शी रुपमा सेवाप्रवाह गर्न संघ, प्रदेश र स्थानीय तहका सवै निकायले सूचना प्रविधिको अधिकतम प्रयोग गरी डिजिटाइजेसनमा ध्यान दिनुपछ। 


\section{(छ) स्रोतको दक्षतापर्ण परिचालन}

कोभिड - १९ ले मुलुक मुलुक बिचमा र मुलुकभित्र असमानता बढाउने भएकाले असमानता घटाउन थप कार्यकम सळ्चालन गर्नुपछ। दिगो विकास लक्ष्य हासिल गर्न सन् २०३० सम्म प्रतिवर्ष रु. २० खर्ब २५ अर्बका दरले लगानी गर्नुपर्ने (राष्ट्रिय योजना आयोग, २०७७, प्. १५) अवस्थामा यस रोगको प्रभावबाट छुटकारा पाउनका लागि त्यसतर्फ ठूलो स्रोतसाधन खर्च गर्नुपर्ने भएकोले थप स्रोतको परिचालन तथा प्राप्तिमा ध्यान दिनुपछ । अनौपचारिक अर्थतन्त्रलाई औपचारिक बनाउनुपछ । वैदेशिक अनुदान, ऋणको साथसाथै राजस्वको सही परिचालन गर्नुपछ।

\section{(ज) सार्वजनिक, निजी र सहकारी क्षेत्र बिच साभेदारी}

\section{र सहकार्य}

कोभिड - १९ को नियन्त्रण कुनै एक निकायको सक्रियताले मात्र हुन सक्देन् त्यसैले संघ, प्रदेश र स्थानीय सरकारका साथसाथै निजी क्षेत्र, सहकारी क्षेत्र, गैरसरकारी संस्था, बाह्य विकास साभेदार र नागरिक समाजको सहभागिता, साभेदारीमा यस रोगको रोकथाम र नियन्त्रण गर्दे अर्थतन्त्रलाई चलायमान बनाउनुपछ ।

\section{निष्कर्ष}

कोभिड - १९ का कारण मानव जीवन र जीविकामा गम्भीर असर परेको छ। यसको असरबाट विश्वका कुनै पनि देश अछुता छैनन् यसले हरेक क्षेत्रलाई असर पारेको छ। नेपाल जस्तो सानो अर्थतन्त्र भएको देशको हकमा पनि यसको चकीय असर छ। यसको रोकथाम तथा नियन्त्रणका लागि अबलम्वन गरिएका उपायका कारण आर्थिक कियाकलाप प्रभावित भएकोमा खुकुलो बनाउँदै लगे पश्चात् आर्थिक कियाकलाप कमश: बढ़दै गएको छ। यस महामारीमा नागरिकको जीवन रक्षाका लागि स्वास्थ्य क्षेत्रमा लगानी बढाउँदै अर्थतन्त्रका गतिविधि चलायमान गराउनुपर्ने देखिन्छ, भने रोजगारी सिर्जना गरी नागरिकको आय वृद्धिमा पनि ध्यान दिनुपर्ने
देखिन्छ । तिनै तहका सरकारले नागरिक जीवनलाई सुरक्षित बनाउादै आम नागरिकमा विश्वास र भरोसाको वातावरण सिर्जना गर्दे राहत र आर्थिक पुनरुत्थानका कार्यकम प्रभावकारी रुपमा कार्यान्वयन गर्नुपछ। साथै, निजी क्षेत्र, नागरिक समाजले यस रोगको रोकथाम र नियन्त्रणमा सरकारसाग सहकार्य र समन्वय गर्नुपछ।

\section{सन्दर्भ सामग्री}

अधिकारी, महाप्रसाद (२०७७), मूल्यमा पर्न सक्ने चाप र वित्तीय स्थायित्वप्रति बैंक सजग छ।

मिर्मिरे आर्थिक विशेषांक, ४५(२), पृ. क - ९।

ओभा, पुरुषोत्तम (२०७७ पुष ५), वैदेशिक व्यापारमा कोरोनाको असर र पुनरुत्थान, कारोवार दैनिक, पू. ६। खतिवडा, युवराज (२०७७), बदलिदो परिवेश र नेपाल, अर्थनीति सेजन स्मारिका, पृ.१२६-१२९।

नेपाल राष्ट्र बैंक (२०७७ असार), कोभिड - 99 ले अर्थतन्त्रमा पारेको प्रभाव सम्बन्धी सर्वेक्षण प्रतिवेदन, काठमाडौं : नेपाल राष्ट्र बैंक।

नेपाल राष्ट्र बैंक (२०७७ मंसिर), कोभिड - 99 ले अर्थतन्त्रमा पारेको प्रभाव सम्बन्धी प्रथम पुनरावृत्ति सर्वेक्षणको प्रतिवेदन, काठमाडौं : नेपाल राष्ट्र बैंक।

नेपाल राष्ट्र बैंक (२०७७ (क) ), देशको वर्तमान आर्थिक तथा वित्तीय स्थिति (आर्थिक वर्ष २०७६/७७ को वार्षिक तथ्यांकमा आधारित), काठमाडौं : नेपाल राष्ट्र बैंक।

नेपाल राष्ट्र बैंक (२०७७ पुष ), देशको वर्तमान आर्थिक तथा वित्तीय स्थिति (आर्थिक वर्ष २०७७/७द को पाच महिनाको तथ्यांकमा आधारित), काठमाडौं : नेपाल राष्ट्र बैंक।

नेपाल राष्ट्र बैंक (२०७७ (ख)), आर्थिक वर्ष २०७७/७५को मौद्रिक नीति, काठमाडौं : नेपाल राष्ट्र बैंक।

नेपाल सरकार, (२०७७), आ.व., २०७७/७६ को बजेट वक्तव्य, काठमाडौं : अर्थ मन्त्रालय ।

अर्थ मत्त्रालय (२०७७), आर्थिक सर्वेक्षण, २०७६/७७ काठमाडौं : अर्थ मन्त्रालय । 
नेपाल सरकार, आ.व. २०७६/७७ को वार्षिक प्रगति मूल्यांकन, काठमाडौं : अर्थ मत्त्रालय ।

नेपाल सरकार (२०७७ साउन), अर्थ बुलेटिन वार्षिक अङक, काठमाडौं : अर्थ मत्त्रालय ।

नेपाल सरकार (२०७७), नेपाल सरकारको वार्षिक नीति तथा कार्यकम, काठमाडौं: नेपाल सरकार ।

बन्जाडे, यज्ञ (२०७७ पुष १२), घट्यो ऋणको व्याजदर, कान्तिपुर दैनिक, पृ.९।

महत, डा.रामशरण (२०७७),पुनरुत्थान र व्यवस्थापन, अर्थनीति (सेजन स्मारिका), पृ.१५ॅ-१६१।

महालेखा नियन्त्रक कार्यालय (२०७७), नेपाल सरकारको आय व्ययको संक्षिप्त कलक आर्थिक वर्ष २०७६/७७, काठमाडौं : महालेखा नियन्त्रक कार्यालय।

राष्ट्रिय योजना आयोग (२०७६), पन्ध्रों योजना (२०७६/७७ - २०५०/५9), काठमाडौं : राष्ट्रिय योजना आयोग।

राष्ट्रिय योजना आयोग (२०७७), कोभिड 99 महामारीबाट मुलुकको आर्थिक सामाजिक क्षेत्रमा पारेको प्रभाव सम्बन्धी अध्ययन प्रतिवेदन, काठमाडौं : राष्ट्रिय योजना आयोग ।

शर्मा, सुधा (२०७७), स्वास्थ्य क्षेत्र : वर्तमान स्थिति र भविष्यका सम्भावनाहरु, अर्थनीति सेजनस्मारिका, पृ. १६४-१६६।

Asian Development Bank (2020 September). Nepal macroeconomic update, 8(2), Kathmandu: ADB, Nepal Resident Office.

International Labour Organization (2020). ILO Monitor: Covid -19 and the world ofwork. https://www.ilo.org/wcmsp5/groups/public/@ dgreports/@dcomm/documents/briefingnote/ wcms_755910.pdf. on 4 January 2021.

International Monetary Fund (2020 October). World economic outlook 2020. Washington DC: International Monetary Fund.
Nepal Stock Exchange Limited (2021), Monthly report 2077 Poush, Retrived from http:// nepalstock.com.np/reports-by-category/2 on 6 Februry 2021.

NPC and UNDP (2020). Nepal Human development report 2020. beyond gradutation: Productive transformation and prosperity. Kathmandu: National Planning Commission and United Nations Development Program.

UNDP (2020). Rapid assessment of socio economic impact of Covid-19 in Nepal. Newyork: United Nations Development Program.

World Bank (2020). Poverty and shared prosperity 2020: Reversals of Fortune. Washington DC: World Bank.

World Bank (2020 Fall). Beaten or broken? Informality and Covid-19. Washington DC: World Bank.

World Health Organization. Coronavirus disease (Covid-19). Retrived from https://www. who.int/news-room/q-a-detail/coronavirusdisease-covid-19. on 6 Februry 2021.

World Health Organization. Coronavirus disease (Covid -19) situation dashboard.

Retrived from https://covid19.who.int/ on 6 Februry 2021. 